\title{
Teaching Feminist Poststructuralism: Founding Scholars Still Relevant Today
}

\author{
Megan Aston \\ School of Nursing, Dalhousie University, Halifax, Canada \\ Email:megan.aston@dal.ca
}

How to cite this paper: Aston, M. (2016). Teaching Feminist Poststructuralism: Founding Scholars Still Relevant Today. Creative Education, 7, 2251-2267. http://dx.doi.org/10.4236/ce.2016.715220

Received: August 25, 2016

Accepted: September 23, 2016

Published: September 26, 2016

Copyright (@) 2016 by author and Scientific Research Publishing Inc. This work is licensed under the Creative Commons Attribution International License (CC BY 4.0).

http://creativecommons.org/licenses/by/4.0/ (c) (i) Open Access

\begin{abstract}
This article presents the experiences of one academic educator/researcher learning about and ultimately teaching feminist poststructuralism (FPS) over 20 years. Ideas from foundational postructural and feminist theorists such as Foucault, Butler, Scott and Weedon are presented and brought together into to a particular understanding of FPS. A discussion of how FPS is applied to health education and research will be presented along with clinical examples. After many years of mentoring and teaching students and colleagues about FPS, the author has created a general guide for beginners to help them use FPS in research and practice. This guide has successfully been used with students and colleagues in Canada as well as with colleagues in Tanzania.
\end{abstract}

\section{Keywords}

Feminist Poststructuralism, Research, Teaching, Learning, Education

\section{Introduction}

I was first introduced to feminist poststructuralism in 1987 when I was a Master's student at Queen's University. The language within this particular theory and methodology excited me. Phrases such as critical pedagogy, oppression, emancipation, power and social construction meant that research I conducted might make a difference in the field of nursing and health education for mothers. I devoured books and articles written by Foucault $(1978,1982,1983)$, Weedon (1987) and other feminist scholars that pushed the limits of my thinking that had been influenced by a more linear scientific paradigm. The perspectives from these scholars, my supervisor Dr Magda Lewis and other graduate students, were refreshing as I was able to discuss other ways of understanding the world in a safe space. These different ways of understanding the world spoke to the type of nurse and activist I believed I was. 
As I read, I saw many similarities between the writings of poststructural and feminist authors. The overlap of ideas such as "power is relational", "the personal is political", "subjectivity and agency", "challenge the status quo" and "oppression is socially and institutionally constructed" helped me to understand how to apply discourse analysis in a particular way. These epistemological and ontological positions helped to clearly frame the inequities that I saw within the profession of nursing and within the institution of mothering.

Once I finished my Masters research thesis, I enrolled in a $\mathrm{PhD}$ program at the University of Toronto that allowed me to continue to explore the use of feminist poststructuralism and its application to nursing and mothering. At that time, there were a few feminist authors writing about poststructuralism including Weedon (1987), Rossiter (1988), Butler (1992) and Scott $(1988,1992)$. I was excited to be able to contribute to this body of research and hoped that this methodological movement would continue to grow.

In 1992, during my $\mathrm{PhD}$ studies, I gave birth to my first daughter and in 1996, three weeks after defending my PhD, I gave birth to my second daughter. The personal experience of becoming a mother during the time of conducting my research about mothering and nursing was an amazing added dimension to my personal life, clinical practice and academic work. The lens of FPS informed my personal, professional and academic worlds. When my daughters were both in school, I was hired as a faculty member at Dalhousie University in 2001 where I continued my research using FPS and mentored graduate students and research assistants in the use of FPS.

\section{Who Is Writing about FPS Now?}

Since studying feminist and poststructuralist scholars in the 80's and 90's I have not found many other scholars who have articulated the combined theory of feminist poststructuralism any better than my original understanding that had been pieced together by reading Foucault, Butler, Scott and Weedon. I did find a book written by Cheek (2000) that is a wonderful introduction to poststructuralism and discourse analysis. These are my "go to" theorists that I continue to cite and encourage my students and research assistants read.

Spending years conducting FPS research has proven to me that this methodology is exactly what is needed to analyze the relations of power that construct experiences of nurses and clients. FPS has the potential to uncover the intricacies of interactions embedded within the health care system in ways that can offer meaningful directions for change to social, institutional and health care practices. I have both the privilege and the challenge to teach graduate students, research assistants and colleagues about FPS so that graduate students can move efficiently through their programs of study and complete comprehensive and meaningful research. This has also allowed me to grow my own program of research through collaborative research studies.

\section{Teaching FPS}

As a graduate student supervisor in nursing and health professions and a principal in- 
vestigator of multiple research studies, I have had the privilege of working with many students and research assistants who bring different worldviews, learning styles and perspectives to the research process and the understanding of FPS. Their unique journeys have required me to teach and mentor them differently and subsequently discover the best way to teach FPS. Feedback from my students and RAs has encouraged me to write this paper, as they believed it would be beneficial to others who want to understand or apply FPS to research and clinical practice. I hope that by sharing my experience and ways of understanding FPS, others will be inspired to use FPS in their own work as I believe this theory and methodology can be used to challenge the status quo and support health system changes.

\section{Guiding Principles and Main Messages within Feminist Poststructuralism}

Before explaining my teaching strategies, I will begin with an overview of my understanding of FPS. Throughout my Masters, PhD and academic career, I have chosen to focus on certain concepts from FPS; concepts that overlap, compliment and ultimately combine to create a synergistic philosophy and methodology that can offer a supportive and critical way of understanding and changing personal, social and institutional practices in a variety of settings. My understanding of feminist methodology has changed over the years; however I still draw on original ideas from Weedon (1987), Butler (1992) and Scott (1992).

The overarching concepts that I will address include 1) Power as relational 2) Binary Opposites 3) Regulated Communications 4) Feminist Theory 5) Discourse Analysis 6) Language and Meaning 7) Beliefs, Values and Practices 8) Subjectivity and Agency.

\section{Power as Relational}

"Power as relational" is the first concept I like to discuss and teach as part of a FPS philosophy and methodology. I believe that it is a revolutionary way to understand the world because it requires us to challenge normative Western assumptions about power that create binary opposites and notions of victimization and blame. It is important to understand the difference between "power relations" and "power". "Power relations" requires us to look at how interactions between people are influenced by social and institutional contexts. In other words, we need to examine the complexities of how different discourses affect people and how people affect different discourses.

Foucault's (1982) writings about the construction of power through regulated communications and the exchange of knowledge are still relevant today. Foucault asserts that there is no uniform or constant way that power relations operate, and uses the term "regulated communications" to focus on power processes that are always dependent upon individual situations. Power is not an entity, it is a relation in which one action may influence the action of others and can only exist when it is put into action. In other words, "what defines a relationship of power is that it is a mode of action which does not act directly and immediately on others. Instead, it acts upon their actions: an action upon an action, on existing actions or on those which may arise in the present or 
the future". (1982: 789). Power is not simply defined as the confrontation between two people, but rather it is the meaning given to the interaction. Therefore, one needs to understand individual intent as well as how institutions and the social context in which the interaction takes place, are involved.

\section{Binary Opposites}

Following an understanding of relations of power it is important to comprehend the concept of binary opposites as part of socially or institutionally constructed subject positions that lock people into stereotypical positions informed by uni-directional or polar ways of understanding power. While Foucault argues that binary opposites are a highly problematic construct he also says it is an important place to start when examining and critically analyzing situations. For example, Foucault offers oppositions such as "the power of men over women, of parents over children, of psychiatry over the mentally ill, of medicine over the population, of administration over the ways people live" (780), as places where one might begin to look at how power operates. However, in order to go beyond these potentially polar ways of understanding power, one needs to acknowledge how power is linked with "knowledge, competence and qualifications", thus lending a starting point from which to understand the "struggles against the privileges of knowledge" (p. 781). More specifically, "what is questioned is the way in which knowledge circulates and functions, [and] its relations to power" (p. 781).

The way in which knowledge is exchanged will provide clues as to how power relations may be involved in a particular exchange. More specifically, we need to pay attention to how people feel when they are communicating with each other and look closely at how exchanging information and ideas affects individuals. This will alert us to how people experience tensions or conflicts and provide a way of interpreting how knowledge is hierarchically ordered "The main objective of these struggles is to attack not so much 'such and such' an institution of power, or group, or elite, or class but rather a technique, a form of power" (p. 781). One needs to analyze the intricacies of interactions in order to understand how power relations are involved in the investments people make in discourse as well as processes of normalization.

\section{Regulated Communications}

Understanding regulated communications can enable researchers and clinicians to view power in a way that can address the process of interactions that are embedded in and constructed through institutions. Foucault (1982) writes that rather than perceiving the state (or the institution of medicine) as "an entity which was developed above individuals, ignoring what they are and even their very existence..." it can be seen as "a very sophisticated structure, in which individuals can be integrated, under one condition: that this individuality would be shaped in a new form and submitted to a set of very specific patterns" (p. 783).

This particular focus on power makes us question the notion that social and institutional ideas are totalizing. When we believe that ideas are exclusively socially and insti- 
tutionally controlling for example from medicine, the church or education, Foucault argues that individuals and groups of individuals will self-monitor their own and others everyday practices. Therefore the problem is not to liberate the individual from the state (or various other institutions) but rather one needs to be liberated from "the type of individualization which is linked to the state" (p. 785). Foucault is well known for writing about the panopticon where inmates at a prison eventually self monitor their behavior even after guards have left their posts in the towers that overlook the inmates.

Self monitoring that is connected to social norms can affect the beliefs, values and practices of people; however, if we also believe that the institution of medicine or the social institution of family do not act directly upon individuals it frees us to look for other ways that power operates between people. The challenge is then to find ways to examine how power operates between people. Feminist theorists in the 1980s and 1990s also offered different methodologies that could examine the inequities and oppression experienced by women. These methodologies included personal and political understandings of power and had the potential to work well with many of the concepts put forth by Foucault. For example, some feminist scholars wrote about discourse analysis that provided a way to understand the complexities of power and personal experiences and how they were influenced by social and institutional constructs.

\section{Feminist Theory}

Butler (1992), Scott (1992) and Weedon (1987) were three feminist theorists who influenced my work at the beginning of my academic career and continue to inform my scholarly work today. A focus on the oppression of women was my starting point and the examples provided by these feminist scholars about gender equity made sense. I also saw a clear connection to other critical social scholars such as Spivak (1988), Bell Hooks (1984), Paulo Freire (1986) and my supervisor Dr. Roger Simon (1991). This led me to use FPS in studies that did not have gender as a central focus because I believed the concepts that originated from a feminist point of view would be relevant; and they were. A feminist analysis offers a framework to understand how all people appropriate and internalize, or conversely, resist and struggle against social, cultural and economic power relations. To quote a well known feminist phrase the personal is political. Weedon (1987) writes:

By feminist critical practice I mean ways of understanding social and cultural practices which throw light on how gender power relations are constituted, reproduced and contested. I begin by considering the relationship between feminism as a politics both of the personal and the social, and theory (preface).

\section{Discourse Analysis}

Weedon is a feminist scholar and has written about the importance of understanding discursive fields as she believes it will provide a systematic way to examine how discourses compete as well as how a person experiences power. "Social structures and processes are organized through institutions and practices such as the law, the political 
system, the church, the family, the education system and the media, each of which is located in and structured by a particular discursive field" (Weedon, 1987: p. 35). Weedon then goes on to discuss how discourses have the potential to govern the unconscious and conscious minds and emotions of people, as meaning is only created within discourses through a network of power relations (p. 108).

In the following quotation, although Weedon is referring to women as part of her feminist methodology, her point can be applied to all people today. "What an event or an experience means to an individual depends on the ways of interpreting the world, on the discourses available to her at any particular moment" (Weedon, 1987: p. 79). A discursive field will affect where and how an individual acts and there may even be different and competing discourses that one must choose from. The popular feminist phrase "the personal is political" continues to guide my own research. It is a powerful statement that reminds me of the connection between personal experiences and social and institutional discourses. It is another overlap between feminism, poststructuralism and discourse analysis. Again, Weedon (1987) describes this idea in the next quotation. "The meaning of experience is perhaps the most crucial site of political struggle over meaning since it involves personal, psychic and emotional investments on the part of the individual. It plays an important role in determining the individual's role as social agent" (p. 79). I also found similarities between Weedon's and Foucault's ideas about relations of power. Weedon states:

Power is a relation. It inheres in difference and is a dynamic of control and lack of control between discourses and the subjects, constituted by discourses, who are their agents. Power is exercised within discourses in the ways in which they constitute and govern individual subjects (p. 113).

Although Weedon wrote from a feminist stance that primarily focused on women, I continue to use her ideas about discourse analysis and apply them to research studies that do not always have women as a focal point. I have used concepts from feminism, poststructrualism and discourse analysis in studies looking at children with intellectual disabilities, clients experiencing obesity, and public health nursing and new mothers. The historical roots of feminism that only focused on the oppression of women has been an important starting point for my research, but I now use a broader and more inclusive lens that is not restricted to any one particular subject position. I believe that feminist poststructuralism can be used across a variety of research areas because of its combination of methodologies that are both inclusive and responsive to relations of power in general. No matter whom the people are, the focus is always on their voices, their experiences, their language and their expressions of meaning about a situation. It is up to the participants to decide what they will share and how they tell their stories that focus on a subject position of their choosing such as gender, race, ability, age, job status or education. How do they define themselves in society?

\section{Language and Meaning}

Based on the work of Foucault and Weedon we can see how the use of discourse analy- 
sis and the concept of power as relational have the potential to deconstruct and offer an in-depth understanding of the experiences of people in a particular way. I agree with feminist scholars who tell us that we should listen to people's stories and trust that they are telling us the "truth". I don't believe we need to "triangulate" or "check" the truth of a person's story because a person's experience can only be told by them and no one else. However, the challenge and question we must ask is "what is the best way to accurately and respectfully represent a person's words and experience?" Over the years, I have noted that this is a common struggle for students. The interpretation of another person's experience is not an easy task. Although the words are typed verbatim from audiotaped interviews, the meaning of their words and experiences must be handled with great care and attentiveness.

Language is a crucial starting point for feminist poststructuralism. Language can serve as an obstacle to understanding or it can be used as the vehicle for freedom and liberation. Our everyday language interprets the concreteness of feelings, thoughts and experiences. The social or institutional language and corresponding meaning produced by institutions or groups of people can influence others to follow "normal" or "every day" ways of living. Another feminist writer from the 1980's wrote about the disconnect that was created for some people when incorporating discursive social meanings. "We simply reproduce the perceptions we have heard spoken by others, from whose experience they are equally far removed" (Haug, 1987: p. 64).

Language always exists in historically specific discourses. This suggests that meaning changes depending on the setting or discursive context. This belief that meaning is always changing runs counter to the dominant discourse of language where meanings tend to be fixed in particular kinds of ways. If one believes there is a universal truth that is expressed in language, this may lead to problems. If we assume that language expresses a specific meaning we become "locked in" to a certain way of thinking and may not be able to accept the experiences of others as different and real. We disregard people's feelings because they do not fit into the "norm". Fixed meanings need to be questioned in order to understand how they came to be. I turn to Weedon again for her explanation of how common sense language can reproduce oppression.

...this common sense, articulated in language, represents quite specific values and interests... It is the medium through which already fixed "truths" about the world, society and individuals are expressed.... These meanings which inevitably favour the interests of particular social groups become fixed and widely accepted as true irrespective of sectional interests. All common sense relies on a naive view of language as transparent and true... (Weedon, 1987: pp. 76-77).

A person will give meaning to their experience through their subjective interpretation. "Meaning is produced within language rather than reflected by language..." (Weedon, 1987: p. 23). This is an important concept to note since it indicates that meaning is not guaranteed but changes depending on the setting. My Masters supervisor Dr. Magda Lewis presented a wonderful cultural example in one of our classes that I use today as a teaching example with my students. She asked us to tell her what choco- 
late chip cookie meant to us. We went around the group sharing our own personal meanings about chocolate chip cookies that included words such as home, warmth, mom, happiness, milk etc. The words were predominantly positive and connected to mothers and home. Dr. Lewis then told us that chocolate chip cookies made her feel guilty because she had not learned how to make them for her children. This was a shocking revelation to me and is a great example to show how discourses create different meanings. I have used this example over the years and have elicited similar responses. However, when I was in Norway recently, this same exercise did not have the same impact. Chocolate chip cookies were not socially part of what mothers did in Norway in 2015 and there were many different meanings and for some no connections at all to chocolate chip cookies. This was a wonderful learning moment showing how cultural differences are constructed. In my own research and teaching I often use the example of breastfeeding and how the meaning associated with breasts shifts between a source of sustenance or sexual objects depending on the context and discourse constructed in different societies. This of course has been written about by many feminist scholars.

\section{Beliefs, Values and Practices}

Clearly, understanding another person's experience requires that we simultaneously pay close attention to a variety of concepts. Beliefs, values and practices are concepts that many poststructural and feminist scholars have incorporated in their writing when referring to experience. Family Health Nurse scholars also use these terms (Wright \& Leahy, 2013) to guide nursing clinical practice and accurately capture a person's experience. I have found that it is very helpful to use the terms beliefs, values and practices to guide analysis and although discourse analysis is not a linear process, it is a good starting point for beginning the process and ensuring that we stop and pay close attention to a person's experiences from their perspective and not ours. I will come back to these ideas in more detail in the section on teaching.

\section{Subjectivity and Agency}

Butler (1992), Scott (1992) and Weedon (1987) provided me with a clear understanding of the importance of combining subjectivity, agency and discourse analysis with Foucault's concepts about relations of power. Butler (1992) asserts that being positioned as a "subject" means one actively participates in their own social constitution and therefore has subjectivity. Subjectivity refers to a person's ability to be conscious of self as well as self-reflexive and able to work with, through and against social discourses that are believed to influence all of us. Scott (1988) agrees and says discourse is defined as not simply a language or a text, "but a historically, socially, and institutionally specific structure of statements, terms, categories and beliefs" (p. 35). Not only is a discursive field part of social relations but it can be influential at a personal level since it can affect

where and how an individual acts, feels and thinks. Another feminist writer Alcoff (1988) has suggested that “...all women can (and do) think about, criticize, and alter 
discourses and thus subjectivity can be reconstructed through the process of reflective practice" (p. 425). This type of reflection has also been referred to as "agency". MacDonald (1991) also agrees that women have the ability to reflect on their own thoughts, actions and relationships in order to continually transform themselves in dynamic and active ways that are socially, culturally and institutionally located. Subjects have agency because they have been constituted through "situations and statuses conferred on them" (Scott, 1992: p. 34). Believing that the subject has not been previously determined but only socially constituted allows Butler to argue that one always has the ability to participate in political fields, meaning one's agency can be utilized. Butler then explains that this is a form of deconstruction as one calls into question present understandings of the subject. "To deconstruct these terms means rather, to continue to use them, to repeat them, to repeat them subversively, and to displace them from the context in which they have been deployed as instruments of oppressive power" (p. 17).

Butler (1992) writes about the need to question one's subject position, which is a form of deconstruction. She says that we need to "suspend all commitments to that to which the term 'the subject', refers, and that we consider the linguistic functions it serves in the consolidation and concealment of authority" (p. 15). For example, claims to truth have been used as a deployment of power (Foucault, 1983), and feminism and other political movements have been addressing this problematic construction of power for quite some time by challenging "truths" in a variety of different ways. Using methods of "deconstruction" can uncover how the power relations inherent in any discourse, and between discourses and individuals, affect access to certain knowledge, beliefs and practices.

Scott (1992) supports Butler's views on the "subject" and incorporates them into her own discussion of "experience". Scott addresses the project of making experience visible, particularly those experiences that are "alternative", hidden or oppressed. She says that we need to go beyond just uncovering the existence of difference and normative practices and that it is imperative that we begin to work at understanding "inner workings or logics" (p. 25) and how they are constituted relationally. Key to her presentation of experience is the understanding that, as subjects are positioned through discourse and historical processes, they produce their own experiences; "It is not individuals who have experience, but subjects who are constituted through experience" (p. 26).

While Scott (1992) agrees with Butler that subjects are constituted discursively, she also believes that because there may be conflicts between various discourses (constructions of meaning), multiple meanings are available to any one subject. Not only can the meaning of an experience shift, but language has also been historically constructed with particular definitions and values that continue to change contextually and historically (Smart, 1990; Spivak, 1988). Spivak (1988) writes, it is a "language that we cannot possess, for we are operated by those languages as well” (p. 78). I would agree that we are regulated by language, but I would also argue that the meaning of words can and do change as we attempt to possess them. Language shifts and changes both historically and contextually depending on meanings available at different times. 
Rather than think about power as a simplistic and stagnant relation, which works from the outside, it should be understood as a mediational tool that is useful to understanding how knowledge exchange is ordered or as Foucault phrases it, how regulated communications can be understood. A focus on difference can reveal how the potential for struggle is created.

\section{Feminist Poststructuralism Challenges Binary Opposites and Victimization}

Mani (1990) a feminist scholar wrote about how victimization needs to be challenged.

The discourse of woman as victim has been invaluable to feminism in pointing to the systematic character of gender domination. But if it is not employed with care, or in conjunction with a dynamic conception of agency, it leaves us with reductive representations of women as primarily beings who are passive and acted upon ( $\mathrm{p}$. 37).

The notion of being either the oppressed or the oppressor is problematic as it relies on the logic of binary opposites. Often, when there is difference between concepts or ideas it becomes constructed as oppositional. Common examples of binary opposites are man/woman, Black/White, dominant/subordinate, good/bad, objective/subjective. What is important to note, however, is that these binary opposites do not simply construct differences, they construct different values (Smart, 1990). This is accomplished because power is exercised through hierarchical binary opposites (Valverde, 1991). Some words have become intricately attached to particular meanings and therefore become locked into rigid (common sense and hidden) ways of understanding. "Fixed oppositions conceal the extent to which things presented as oppositional are, in fact interdependent-that is they derive their meaning from a particularly established contrast rather than from some inherent or pure antithesis" (Scott, 1988: p. 37).

Understanding difference through relations of power is meant to provide a way of escaping the reproduction of existing hierarchies. Challenging binary, simplistic and totalizing notions of power, can also uncover the hidden ability of people to create and use power within various discourses (Butler, 1992; Mohanty, 1988; Scott, 1992; Smart, 1990; Valverde, 1991). This would take into account first, how power relations work to perpetuate binary opposites, and secondly how power could be utilized differently from the positions of individuals and groups.

Poovey (1988) another feminist scholar, wrote about the potential of "in-between spaces" and how they could lead us to understand power relations in other ways, as well as see the differences among women. This of course can be applied to anyone, not just women. Scott (1988) wrote that feminist theory could "enable us to articulate alternative ways of thinking about (and thus acting upon) gender without either simply reversing the old hierarchies or confirming them. And we need theory that will be useful and relevant for political practice" (p. 33). Alternative ways of thinking can be applied not only to gender, but also to race, abilities, culture and any other socially constructed positioning. 


\section{Teaching Feminist Poststructuralism}

Whenever I have the opportunity to present research findings at a conference or class, through a 20 minute oral presentation, 10 minute poster presentation or 2 hour class, I always begin by explaining how FPS shifts our understanding of power to relational and in a way that can challenge every day practices and oppression seen in the form of stigma and stereotypes. This is often a good place to start; however I am also aware that many people continue to be uncomfortable with terms such as oppression and feminism. Feminism may conjure up negative images of radical, retaliating, bra burning feminists who hate men, and oppression is often seen to only include extreme circumstances such as slavery, abuse or torture. Extremist stances often turn people away from conversations, so my challenge has been and continues to be what language I should use with different audiences. What is the best way to engage people? I usually like to explain that feminism has evolved and can include a critical social analysis on all subject positions such as gender (men and women), race, abilities etc. This seems to set the stage for a more equitable discussion. Students tell me that my passion for FPS comes through in my teaching and research and therefore I have taken it upon myself to share FPS with as many people as possible.

When working with graduate students or research coordinators I first encourage them to read the experts such as Foucault, Butler, Scott, Weedon and Cheek because I believe that their philosophies and methodologies are still applicable and relevant today. However, together we continue to critique the writings of these scholars and contextualize the methodologies to ensure they are still relevant to the populations we are studying and the discourses we are analyzing. Not only have I mentored students in the use of FPS, I have also mentored colleagues in Canada and Tanzania. Colleagues in Tanzania have found FPS to be relevant and useful as we are able to clearly articulate and see the unique cultural and institutional discourses in Tanzania and how the meaning of experience is different from Canadian contexts.

After many years of teaching FPS I was aware that I was using the same steps, examples and eventually diagrams that worked well. The concepts used in FPS need to be interactive and fluid in application and while I do not agree with a linear application of concepts I have developed a guideline that can help those who are new to feminism, poststructuralism and discourse analysis (see Table 1).

All of my research studies and those of my students have included the analysis of verbatim transcripts from individual and focus group interviews either in person or over the phone; therefore, this guide has been created based on this type of research. Because it is imperative that the meaning of participants' experiences must come from the participants themselves we of course start with the quotations. While this might seem to be an easy task, it is not. As described earlier in this article it is often challenging to ensure you are representing the intended meaning presented by participants. In order to stay true to the experience of participants we pay very close attention to their beliefs, values and practices. In the following sections I describe how to apply FPS as outlined in Table 1. 
Table 1. A guide to using FPS informed by discourse analysis.

1) Identify important issues

2) Applying beliefs, values and practices

3) Social and institutional discourses
Read the transcript and mark quotations you feel represent an important issue. Name the issue as you see it.

Provide the quotation (cut and paste) and write something about the Belief, Value and Practice within the quotation.

Write about the social and institutional discourses you see informing the issue you identified. Sometimes this is clearly described in the quotation but most often you need to expand on the implied ideas. You still need to clearly connect to the evidence (words and meaning provided by participant).

As you write about the discourses, you need to connect these ideas to the 4) Responding to relations of participant. How do the discourses affect the participant? Does he/she agree or power

disagree with the beliefs, values and practices? Is it an easy or positive fit? Or are there questions, conflicts, tensions, etc? These are the "relations of power" that the participant is feeling/experiencing.

You can also add in the participant's "subjectivity" (how they are positioned as 5) Subjectivity and agency a nurse, man, woman, teacher etc) as well as their "agency" (how they choose to act in each situation by fitting in or challenging).

\section{Identifying Important Issues}

To begin analysis I always have at least two people read a transcript. The initial analysis is done separately so that individuals can identify issues that they believe are important to the participant and related to the research question. I tell students to read the transcript and mark quotations they feel represent an important issue and then name the issue as they see it. Those who are analyzing then come together and compare notes. The majority of the time, the issues identified as important by each of us are the same or very similar. This speaks to the dependability of the analysis when more than one person sees the same thing. At this stage, I purposefully use the term issue because the analysis needs to be kept open or lose so as not to focus too quickly. I do not code as this has the potential to restrict meaning too quickly. It also assumes that participants will all have similar experiences. While there may be similarities, it is dangerous to lead with this notion as it may restrict the analysis process and ultimately exclude diversity and unique experiences. I do not like to use the term "outlier experience" as this perspective may continue to perpetuate exclusion and marginalized voices, whereas FPS supports inclusion of all voices and diversity with the intent of searching for other perhaps invisible voices-a suggestion from some feminist and critical social theorists. Therefore, it is important to include unique experiences. Saturation, is another problematic concept as this means the researcher is only looking for commonalities therefore, I choose not to assume saturation will occur. Social and institutional constructs may create the opportunity for people to have similar experiences and therefore we do look for similarities and eventually themes, while at the same time being as "open" as possible with analysis.

\section{Applying Beliefs, Values and Practices}

In order to pay close attention to and begin to deconstruct an issue identified in the transcript, analysis needs to start with the perspective of the participant (not the re- 
searcher). I have found that by focusing first on the beliefs of the participant it forces us as researchers to suspend our own beliefs. A belief is something that a participant articulates in the interview and is much more than a statement or description about a situation. For example if a nurse states "we work long hours in the hospital and have 8 patients each", this is a neutral statement and does not tell us anything about his/her belief. However, if the nurse said "we should not be working long hours or have 8 patients, this is too much for us" we could interpret this as the nurse believing the work-

load is "too much". Beliefs are personal opinions and therefore, it is important to pay attention to the way the participant talks about a situation. Similarly, a value is a personal perspective from the point of view of the participant. If the nurse continued and said "we need to get back to a more balanced work load so that we can offer better care and not have to be so stressed", we could interpret this as valuing a balanced workload, good care for patients and good mental health for the nurse. Once we have identified the belief and value of a situation we need to understand the nurse's practice in relation to his/her beliefs and values. If the nurse said: "This is the way it has always been. I feel badly for the patients so I keep on going and ethically I can't quit", we might interpret this as a moment of tension where the nurse identified a difficult situation where he/she had to "choose" a course of action. The nurse chose to work within the parameters of institutional guidelines; however we also need to look at how the institutional discourse constructed with other beliefs and values impacted his/her decision.

\section{Social and Institutional Discourses}

After identifying direct quotations from participants that clearly present their beliefs, values and practices about a particular issue, the next step is to make connections to social and institutional discourses in a way that incorporates relations of power. Continuing with the above example, we could say that the institutional discourse of the hospital included a belief that it is necessary for nurses to have 8 patients each and work overtime when necessary. We could also include social discourses about nursing that construct the image and practice of nurses to be selfless and caring. Carefully looking at the words and circumstances of this nurse might lead the analysis in this direction.

\section{Responding to Relations of Power}

The next step or parallel part of the analysis is to look at how participants respond to relations of power and social and/or institutional discourses. The nurse clearly identified a moment of tension when expressing his/her beliefs about patient care and workload as they were different from those of the institution. From this nurse's experience we can see that the expected practices within the hospital were constructed through a relation of power that expected nurses to have a certain number of patients and work overtime. Clearly this nurse had to negotiate relations of power and might have felt pressured to work within oppressive institutional conditions.

\section{Subjectivity and Agency}

To fully understand how this nurse might have been experiencing the tension and institutional expectations we need to look carefully at how he/she felt and expressed him/herself. When developing questions for a semi-structured interview guide I always 
include feeling questions or probes. I tell my students and RAs that they need to ask their participants "How did that make you feel?" or "How did you feel about the situation?" This type of question helps to focus the interview on the participant's personal experience and provides more depth to the conversation to see how participants position themselves and choose to act in certain situations. As we look at how the participants react to and negotiate relations of power we can understand how they use their subjectivity and agency. For example, this participant was subjectively positioned to work as a nurse in a hospital with certain institutional guidelines. However, the nurse is also subjectively positioned through a social discourse on nursing and an educational discourse. Nurses are trained and monitored to practice ethically and to implement evidence based practice. The dilemma for this nurse arose through conflicting social, educational and institutional discourses related to nursing practice. The nurse used his/her agency evidenced by the statement "we work long hours in the hospital and have 8 patients each". We can clearly see the nurse's belief contradicts the expectations of the hospital. Although the nurse did not overtly challenge the practice by going to the manager or union, we can interpret thoughts as challenging and perhaps there were other instances where the nurse spoke with and had support from other nurses.

\section{Conclusions}

FPS is a philosophy, theory and methodology that focuses on understanding relations of power through discourse analysis. It has enabled me to examine issues of social justice in the health care system as I explored relations of power between health care professionals and clients. FPS guides analysis in a way that interrogates the meaning of words by paying close attention to the way participants tell their stories. We can see how they negotiate their own personal beliefs, values and practices in relation to social and institutional discourses that may hold different beliefs, values and practices. Many students I have taught have said to me that learning about FPS has been a revolutionary experience and for them, it has changed the way they look at the world. Having a methodology, lens, or new worldview to support a critical analysis of personal, social and institutional practices can be exciting. This has been my experience since being introduced to FPS as a Masters student and I enjoy teaching and mentoring others to use FPS, particularly when they also find it useful and can answer not only their research questions but also questions about everyday practices.

I believe that FPS has been marginalized as a methodology because of its association with feminism and power. However, I have found that using FPS actually shifts the way power is examined to take blame away from individuals and institutions. It challenges victim blaming and binary ways of understanding the world to offer a different interpretation of a situation and a way of challenging oppression. As Foucault points out, we cannot blame institutions, as institutions cannot act upon people, rather we need to look at the different discourses and the way people accept or challenge different ideas. It is only then that we can see how things become labeled as marginalized, hegemonic, oppressive, liberating, etc. Labels don't tell the whole story and FPS provides a way to 
uncover the details in a respectful and critical way. I am often reminded of a phrase spoken by my PhD supervisor Dr. Roger Simon, "critical analysis can lead to many possibilities for change". This phrase keeps me going in my work as a nurse, researcher and educator to contribute to a just and caring health care system. Not only do participant experiences show us the challenges of negotiating relations of power, but they also provide solutions because they have lived it. Questioning and disrupting everyday practices has the potential to ensure we are attending to different discourses in an equitable way. FPS is one methodology that can help us with this goal and I am committed to teach and mentor others as I was mentored. I look forward to continuing the dialogue and learning from colleagues and students.

I am thrilled to say that many of my students have used FPS for their Masters and $\mathrm{PhD}$ research studies and have written articles applying FPS to their clinical practice as nurses. My colleagues and I have used and continue to use FPS in our research studies that span a variety of health issues including postpartum care of mothers, caring for intellectually disabled children and obesity management. The following is a list of articles and dissertations by faculty and students who used FPS (Abudulai, 2014; Aston et al., 2016, Aston et al., 2014a, Aston et al., 2014b, Aston et al., 2014c, Aston et al., 2014d, Aston et al., 2011; Bye \& Aston, 2016; Cassidy et al., 2016; Griscti, 2015, Griscti et al. 2016; Kirk et al., 2014; MacConnell et al., 2012; Price et al., 2015; Sheppard-Lemoine, 2015).

\section{Acknowledgements}

I would like to acknowledge and thank my supervisors Dr. Lewis and Dr. Simon as well as all the students who I have worked with and learned from throughout my academic journey. In particular I would like to thank Danielle Macdonald for her support and editing of this article.

\section{References}

Abudulai, E. (2014). Maternal Bodies and Obesity: Rethinking Dominant Perspectives, Exploring A Path Less Travelled. Master's Thesis, Can Be found at Theses Canada. http://www.collectionscanada.gc.ca/obj/thesescanada/vol2/NSHD/TC-NSHD-54071.pdf

Alcoff, L. (1988). Cultural Feminism versus Poststructuralism: The Identity Crisis in Feminist Theory. Signs Journal of Women in Culture and Society, 13, 405-436. http://dx.doi.org/10.1086/494426

Aston, M., Breau, L., \& MacLeod. E. (2014b). Understanding the Importance of Relationships from the Perspective of Children with Intellectual Disabilities, Their Parents, and Nurses. Journal of Intellectual Disability, 18, 221-237.

Aston, M., Breau, L., \& MacLeod. E. (2014d). Diagnoses, Labels and Stereotypes: Supporting Children with Intellectual Disabilities in the Hospital. Journal of Intellectual Disabilities, 18, 291-304.

Aston, M., Etowa, J., Price, S., Vukic, A., Hart, C., MacLeod, E., \& Randel, P. (2016). Public Health Nurses and Mothers Challenge and Shift the Meaning of Health Outcomes. Global Qualitative Nursing Research, 3, 1-10. http://dx.doi.org/10.1177/2333393616632126 
Aston, M., Price, S., Etowa, J., Vukic, A., Young, L., Hart, C., MacLeod, E., \& Randel, P. (2014a) The Power of Relationships: Exploring How Public Health Nurses Support Mothers and Families during Postpartum Home Visits. Journal of Family Nursing, 21, 11-34.

Aston, M., Price, S., Etowa, J., Vukic, A., Young, L., Hart, C., MacLeod, E., \& Randel, P. (2014c). Universal and Targeted Early Home Visiting: Perspectives of Public Health Nurses and Mothers. Nursing Reports, 4, 12-18.

Aston, M., Price, S., Kirk, S., \& Penney, T. (2011) More than Meets the Eye. Feminist Poststructuralism as a Lens towards Understanding Obesity. Journal of Advanced Nursing, 68, 11871194. http://dx.doi.org/10.1111/j.1365-2648.2011.05866.x

Butler, J. (1992). Contingent Foundations: Feminism and the Question of "Postmodernism". In J. Butler, \& J. Scott (Eds.),Feminists Theorize the Political (pp. 3). New York and London: Routledge, Chapman and Hall, Inc.

Bye, A., \& Aston, M. (2016). Brenna's Story: A Critical Reflection and Analysis of One Mother's Experience of Navigating the Medical System with a Child with an Intellectual Disability. Journal of Intellectual Disabilities, 20, 82-92.

Cassidy, C., Goldberg, L., \& Aston, M. (2016). The Application of a Feminist Post-Structural Framework in Nursing Practice for Addressing Young Women's Sexual Health. Journal of Clinical Nursing, 25, 2378-2386. http://dx.doi.org/10.1111/jocn.13354

Cheek, J. (2000). Postmodern and Poststructural Approaches to Nursing Research. Thousand Oaks, CA: Sage Publications.

Foucault, M. (1978). The History of Sexuality: An Introduction Volume 1. New York: Random House Incorporated.

Foucault, M. (1982). The Subject and Power. Critical Inquiry, 8, 777-795. http://dx.doi.org/10.1086/448181 http://www.unisa.edu.au/Global/EASS/HRI/foucault_-_the_subject_and_power.pdf

Foucault, M. (1983). The Subject and Power. In H.L. Dreyfus, \& P. Rabinow (Eds), Beyond Structuralism and Hermeneutics (pp. 208-228). Chicago, IL: U of C Press.

Freire, P. (1986). Pedagogy of the Oppressed. New York: Continuum.

Griscti, O. (2015). The Experiences of Chronically Ill Patients and Registered Nurses When They Negotiate Patient Care in Hospital Settings. PhD Thesis, Can Be Found at Theses Canada. http://www.bac-lac.gc.ca/eng/services/theses/Pages/theses-canada.aspx

Griscti, O., Aston, M., Martin-Misener, R., Warner, G., \& McLeod, D. (2016). The Experiences of Chronically Ill Patients and Registered Nurses When They Negotiate Patient Care in Hospital Settings: A Feminist Post Structural Approach. Journal of Clinical Nursing, 25, 2028-2039. http://dx.doi.org/10.1111/jocn.13250

Haug, F. (Ed.) (1987). Female Sexualization. London: Verso.

Hooks, B. (1984). Feminist Theory: From Margin to Center. Cambridge, MA: South End Press.

Kirk, S. F. L., Price, S., Penney, T. L., Rehman, L., Lyons, R., Piccinini-Vallis, H., Vallis, T. M., \& Aston, M. (2014). Blame, Shame and Lack of Support: A Multi-Level Study of Obesity Management. Qualitative Health Research, 24, 790-800. http://dx.doi.org/10.1177/1049732314529667

MacConnell, G., Aston, M., Randel, P., \& Zwaagstra, N. (2012). Nurses' Experiences Providing Bereavement Follow-Up: An Exploratory Study Using Feminist Poststructuralism. Journal of Clinical Nursing, 22, 1094-1102. http://dx.doi.org/10.1111/j.1365-2702.2012.04272.x

MacDonald, E. (1991). The Trouble with Subjects: Feminism, Marxism and the Questions of Poststructuralism. Studies in Political Economy, 43-71. http://dx.doi.org/10.1080/19187033.1991.11675452 
Mani, L. (1990). Multiple Mediations: Feminist Scholarship in the Age of Multinational Reception. Feminist Review, 35, 24-41. http://dx.doi.org/10.1057/fr.1990.26

Mohanty, C. (1988). Under Western Eyes: Feminist Scholarhsip and Colonial Discourses. Feminist Review, 30, 61-85. http://dx.doi.org/10.1057/fr.1988.42

Price, S., Aston, M., Rehman, L., Lyons, R., \& Kirk, S. (2015). Feminist Post-Structural Analysis of Obesity Management: A Relational Experience. Clinical Nursing Studies, 3, 76-86. http://dx.doi.org/10.5430/cns.v3n3p76

Rossiter, A. (1988). From Private to Public: A Feminist Exploration of Early Mothering. Toronto: The Women's Press.

Scott, J. (1988). Deconstructing Equality-versus-Difference: Or, the Use of Poststructuralist Theory for Feminism. Feminist Studies, 14, 33-50. http://dx.doi.org/10.2307/3177997

Scott, J. (1992). Experience. In J. Butler, \& J. Scott (Eds.), Feminists Theorize the Political (pp. 22-40). London: Routledge, Chapman and Hall Inc.

Sheppard-Lemoine, D. (2015). Within Vulnerability: Understanding the Practices and Experiences of Enhanced Home Visiting Public Health Nurses and Community Home Visitors. PhD Thesis, Can Be Found at Theses Canada.

http://www.bac-lac.gc.ca/eng/services/theses/Pages/theses-canada.aspx

Simon, R. (1991). Teaching against the Grain: Texts for a Pedagogy of Possibility. Toronto: OISE Press.

Smart, C. (1990). Law's Power, the Sexed Body, and Feminist Discourse. Journal of Law and Society, 17, 194-200. http://dx.doi.org/10.2307/1410085

Spivak, G. (1988). In Other Words. Essays in Cultural Politics. New York: Routledge.

Valverde, M. (1991). As If Subjects Existed. Analysing Social Discourses. Canadian Review of Society and Anthropology, 28, 173-187. http://dx.doi.org/10.1111/j.1755-618X.1991.tb00150.x

Weedon, C. (1987). Feminist Practice and Poststructuralist Theory. New York: Basil Blackwell Ltd.

Wright, L. M., \& Leahey, M. (2013). Nurses and Families: A Guide to Family Assessment and Intervention (6th ed.). Philadelphia, PA: FA Davis Company.

Submit or recommend next manuscript to SCIRP and we will provide best service for you:

Accepting pre-submission inquiries through Email, Facebook, LinkedIn, Twitter, etc.

A wide selection of journals (inclusive of 9 subjects, more than 200 journals)

Providing 24-hour high-quality service

User-friendly online submission system

Fair and swift peer-review system

Efficient typesetting and proofreading procedure

Display of the result of downloads and visits, as well as the number of cited articles

Maximum dissemination of your research work

Submit your manuscript at: http://papersubmission.scirp.org/

Or contact ce@scirp.org 